Open Access

\title{
The logical problem of scaffolding in second language acquisition
}

\author{
Esmaeel Hamidi * (D) and Rafat Bagherzadeh
}

\author{
* Correspondence: hamidi_ela@ \\ yahoo.com \\ Department of English Language, \\ School of Health Management and \\ Information Sciences, Iran University \\ of Medical Sciences, Tehran, Iran
}

\begin{abstract}
Scaffolding is one of the key dimensions of the sociocultural theory that has been proposed in a substantial body of work as a potential metaphor for promoting second language (L2) learning. However, there is plenty of evidence that the term is misinterpreted and presents a number of epistemological problems. The first and foremost concerns the phenomenological nature of scaffolding in the sense that the original conception of the notion does not support its implication in mainstream second language acquisition (SLA) contexts. To substantiate the claim, we have proposed four underlying factors, including predictability, variability, mediation, and restructuring. The second has to do with the range of variation in the conceptual meaning of scaffolding, which normally leads to a state of confusion in the operational definition of the term in the SLA practice and research. Reviewing the texts, we have then found three fundamental points in the definitions of scaffolding, each with specific logical and methodological problems. From the above evidence, it can be argued that scaffolding is not a construct that meets the pedagogical goals of $L 2$ learning and development. The paper then concludes that as long as the nature of scaffolding and its underpinnings in SLA are at stake, future research on the notion will most likely suffer a severe loss of pedagogical and intellectual validity.
\end{abstract}

Keywords: Scaffolding, Predictability, Variability, Mediation, Restructuring, SLA, ZPD

\section{Introduction}

An issue historically central to the field of second language acquisition (SLA) research is Bruner's (1983) proposition of "scaffolding" as a metaphor to theorize an assistance mediated through interaction to help a child to perform a new task or function. The notion is inspired by Vygotsky's (1978) socio-cultural theory of learning, specifically the notion of Zone of Proximal Development $(Z P D)$ which is conventionally defined as the cognitive gap between what learners can do unaided and what they can do with assistance (Lantolf 2011). A prevailing assumption of scaffolding has originally been that for an assistance to become effective, it needs to occur within the learner's ZPD (e.g., Scollon 2002; Lantolf 2000a, 2009; Nassaji and Fotos 2011). The rationale behind the term has increasingly led to the development of much empirical work and theoretical debate in SLA, especially over the recent decades (e.g., Donato 1994; De Guerrero and Villamil 2000; Nassaji and Cumming 2000; Storch 2002; Cotterall and Cohen 2003; Gibbons 2003). Despite the increasing prominence given to scaffolding in SLA research, the equivocal, yet evasive, conception of the notion from its earliest hypothetical

(C) The Author(s). 2018 Open Access This article is distributed under the terms of the Creative Commons Attribution 4.0 International License (http://creativecommons.org/licenses/by/4.0/), which permits unrestricted use, distribution, and reproduction in any medium, provided you give appropriate credit to the original author(s) and the source, provide a link to the Creative Commons license, and indicate if changes were made. 
framework together with "the [current] ambiguous status of the notion of ZPD, and the attendant pedagogizing of it in the processes of scaffolding" (Van Lier 2004, p. 15), have led to a proliferation of sundry interpretations and refurbishments. Some of these metaphorical concepts include apprenticeship (Rogoff 1990), assisted performance (Van Lier 2004), collaborative dialogue (Swain 2000), collaborative discourse (Ellis 1990), contingency (Van Lier 1992), mediated discourse/action (Scollon 2001, 2002), pedagogical interaction (Donato 2000), personal correspondence (Lantolf 2000b), strategic mediation (Johnson 2009), etc. Likewise, as Van Lier (2004) comments, scaffolding is now alluded to any 'helping' or 'teaching', and "the construct is in danger of becoming meaningless" (p. 15).

Although scaffolding has gained great recognition in the research and development of SLA over the recent decades, the term has developed into an obscure and equivocal construct in a number of respects. Everyone studying second language (L2) education may know that scaffolding, above all, has a non-academic background. Later, the notion has embraced an academic, but inconsistent and elusive, implication in SLA. Put very simply, there is lack of correspondence between the original conception of 'scaffolding' and its conventional implication in SLA. Furthermore, reviewing the research literature on scaffolding provides evidence that SLA scholars have not been clear at establishing straightforward definitions of the term, and the varying definitions and interpretations proposed on scaffolding in the context of SLA have been rather inconsistent and elusive.

From the above body of discussion, it appears very doubtful whether student learning results directly from scaffolding process because, as Watson-Gegeo \& Nielsen (2003, p. 162) stated, there are certain individual and formative contextual factors such as "the sorts of situations for learners to participate, the roles they can assume, and the linguistic, sociolinguistic, and discoursal complexity of oral or written language forms" that may influence or determine the process of L2 learning.

Also, central to the critical orientation in the present paper is the pedagogical goals that have been depicted for scaffolding in SLA context. Many scholars in the field (e.g., Donato 1994; Nassaji and Cumming 2000) suggest that scaffolding promotes learning or fosters L2 development. An in-depth inquiry into the research on the effect of scaffolding on L2 development in SLA provides no strong empirical evidence to demonstrate whether, and to what extent, it enhances interactional processes among the target language learners, builds up learners' target language proficiency, contributes to learners' greater noticing to the target language features, boosts learners' self-confidence, autonomy, and motivation, and displays more social roles in their classroom learning. Moreover, no empirical studies, as far as our knowledge permits, have actually confirmed the impact of scaffolding on L2 learners' interlanguage development.

Drawing on the extant body of research in applied linguistics, especially in SLA, as well as theoretical arguments, the present paper is therefore intended to clear up the nebulous clouds of scaffolding used in the mainstream milieu of SLA.

\section{Phenomenological nature of scaffolding and its implication}

Scaffolding is now widely conceptualized in SLA research as a dialogic process structured asymmetrically (i.e., by interactants of unequal status) through contextual, intellectual support, assistance or guidance from one interactant to another to accomplish new tasks or functions (e.g., Applebee and Langer 1983; Bailey 2006; Littlewood 2004; Mercer 2001; 
Scolon, 2001; Van Lier 2001). The process is actually purported to occur via what Scolon (1976) refers to as 'vertical constructions' or what Donato (1994) reports as 'collective scaffolding,' which demonstrates how interactants can jointly construct knowledge (Van Lier 2004). Although the recent characterizations focus more on the symmetrical representation of scaffolding (i.e., assistance given by interactants of equal status), the overriding assumptions underlying Vygotsky's ZPD centers around asymmetrical conception of the scaffolding construct, though it does occur somehow in and through interactions.

There is no doubt that scaffolding takes its origin from physical architecture (Van Lier 2004), where everything comes through physical, concrete operations, and later, appeared in the L1, and then L2, acquisition research, which was assumed to allow for cognitive and social/ecological operations.

Drawing on the phenomenological tradition of inquiry, we believe that the association between the original nature of scaffolding and its purported implication in SLA is open to question. To substantiate the claim, we have proposed four underlying factors, including predictability, variability, mediation, and restructuring. Basically, scaffolding developed with concrete operations, as it appears in painting, is highly predictable in the sense that the agent (i.e., the scaffold) seeking for assistance is obviously an entity that fulfills the expectations of or is highly constrained by and therefore indisputably subordinate to the patient (i.e., one who receives the support) when adopting mentally-driven physical actions to complete a task. However, predictability is hardly feasible, especially due to the complex operations of L2 learning as well as the complex structure of human mind. Suffice it to say, implementing the task-as-process (see Breen 1989; Ellis 2003; Seedhouse 2004, 2010) is not a simple undertaking to be carried out with controlled measure of any learning variables within the cognitive and social domains; rather, it requires the consideration of the learner's idiosyncratic, cognitive, cultural, and social and/or ecological factors, the variable features of a dynamically complex, communicative environment of L2 learning, the changing, distinctive characteristics and functions of the task(s) in action, the influx of the construct-irrelevant factors coming around as obstacles to the learning process, etc. (see, e.g., Ellis 1990, 1994; Segalowitz 2003; Skehan 2000).

Another key issue that questions the implicational inception of scaffolding into SLA is what we call variability. In practice, the scaffold used in, say, painting is rather rigid and static (Van Lier 2004) and functions in conformity with the variable thinking processes of the scaffolded or assisted being to decide on the potential performances. Put it another way, the scaffold undergoes no intra-agent variability and, therefore, assumes no role in inter-agent variability although it "permits work to be conducted that would not be possible without the scaffold" (Van Lier 2004, p. 148). It is an other-regulated, dependent, or allocentric, entity but not a self-regulated, other-regulating entity. At the other end of the spectrum in SLA, it is safely argued that despite the dynamicity and flexibility of the educational work in general, as its name suggests (Van Lier 2004), learners survive with variability, certainly thanks to the acknowledged variability of interlanguage (Larsen-Freeman 1991; Ellis 1990, 1994; Tarone 1990). The major focus of the argument is that such variability occurs synchronically, whether the learner is self-assisted (through self-regulated thinking) or other-assisted (through instruction and interaction). This all implies that the learner, i.e., the so-called scaffolded being, tends to come up with both intra-learner and 
inter-learner variability during the learning process, and as the learner demonstrates further learning (Ellis 2003), such variability becomes greater. So it is normally clear that the original relevance of scaffolding doesn't support its implication in SLA.

The third issue has to do with the mediation that is provided to the structure of scaffolding. By comparison, scaffolding in the physical architecture is preplanned or premeditated with reference to the physical target. In other words, it doesn't emerge as a result of, for example, the painter's immediate acknowledged failure or inability during the painting process. Vygotsky's notion of Zone of Proximal Development $(Z P D)$ posits that the social mediation, i.e., scaffolding, occurs within the distance or the cognitive gap between what the learner can do unaided and what he/she can do aided (Lantolf 2000a). The mediation is implied to take place when the gap is noticed (Ellis 1994) during either the asymmetrical or symmetrical construction, and it is therefore argued that unlike the scaffolding in the physical architecture, such as painting, SLA assumes no premediation of assistance in the ZPD framework.

Finally yet importantly, scaffolding fails to be a means or an incentive for initiating reorganization, or restructuring, of performance. This is because the scaffold supports as it is set and has no life to induce reorganization whenever the assisted being fails to perform as expected. In addition, the need for reorganization typically involves resetting the prop. So it can be argued from the empirical, and logical, lens of the issue that there is not any deduced relationship between the assistance the scaffold provides and the scaffolded being's better performance. This is so while in human learning, especially from the SLA point of view, restructuring in general refers to the qualitative changes in behavior beyond automatization, and normally involves reorganization of the behavior into new forms or units (McLaughlin 1987, 1990; Ellis 1990, 1994, 2003). This is primarily a cognitive processing where the learner needs to impose organization on the acquired knowledge to structure new information (McLaughlin 1990). According to Karmiloff-Smith (1986, also cited in McLaughlin, 1990), the evolving restructuring process goes through three recurrent phases, which moves from simple modes of organization to more complex operations: (1) a data-driven phase, where there is indication of mastering the task, but no attempt at overall organization; (2) the organization phase, where learners impose the organization on the learning behavior as a result of attempts at simplification, unification, and domination over the internalized representations; and (3) the integration phase, where the learner incorporates the cognitive processes in the preceding phases arising from online restructuring, and then goes beyond the mere automatization when enhanced by ecological feedback (italics added). Since there is more to the argument, it is the restructuring point of view that learning involves a sustained modification and reconstruction of the acquired organizational knowledge (McLaughlin 1990), and that, as Lightbown (1985), McLaughlin (1987) and Widdowson (2003) argue, L2 learning is not simply linear and cumulative. Rather, it is characterized to be adaptive and "a process of recurrent unlearning and relearning" (Widdowson 2003, p. 141). Therefore, as it has been mentioned earlier, scaffolding in building cannot function as ecological feedback to generate automatization and restructuring toward further organizational structures or performances, a process that emanates from human cognition which is active and dynamic in nature. 


\section{Definitions and conceptual dimensions of scaffolding}

While the earlier conceptualization of scaffolding in the first language acquisition context is quite clear, the construct has experienced significant variations in meaning and definition in SLA (Van Lier 2004). The reason behind such conceptual variations resides mostly in the substantial subjectivity of the construct itself. Many of the notions that have been developed to define and depict scaffolding spring most probably from the writers' conceptual dimensions and judgments because of the abstract, qualitative, highly interpretable, and objectively non-measurable nature of the term. It is subjective because the properties the people apply to define it are also subjective, relative and unobservable. Furthermore, the obscurity in the previously-developed notions on scaffolding normally adds greater weight to the subjectivity of the construct, affording a vehicle for further notional constructions.

The range of variation in the conceptual meaning of scaffolding normally results in a state of confusion in the operational definition of what really constitutes it in the SLA research and practice. Reviewing these definitions, we have found three contentious points that have been foregrounded above all else. These points are summarized as (1) the status of the prompter and receptor of scaffolding; (2) the inability zone of language production; and (3) the temporary state of support.

\section{Status of the prompter and receptor}

Historically speaking, there have been serious attempts to inspire rigorous characterizations of who really scaffolds and who receives scaffolding when it comes to the issue of learning a second language. Thus, the prompter of assistance, variously addressed as either a teacher or a different other, has been described as more knowledgeable (Nassaji and Cumming 2000; Swain and Suzuki 2008), more capable (Van Lier 1996), more experienced (Macaro et al. 2010), an expert (Ellis 1994; Ellis 2003; Ellis 2008; Littlewood 2004; Gibbons 2001; Mitchell and Myles 2001; Saville-Troike 2006; Weissberg 2006), more competent (Van Lier 2001; Myles et al. 1998), more skilled (Applebee and Langer 1983), more effective (Mercer 2001), more proficient (Breen 2001), more able (Storch 2002), a knower (Nyikos and Hashimoto 1997; Bailey 2006), etc. On the other side, the receptor of assistance was categorically portrayed by these, and other, writers to be less knowledgeable, less capable, less experienced, not an expert or a novice, less competent, less skilled, not a knower, less effective, less proficient, less able, etc.

Regardless of what conceptual logic lies behind each author's portrayal of the prompter and the receptor of scaffolding, the overall conceptualization falls into confusion for a number of reasons. For the most part, the descriptive constructs used to define, and categorize, the prompter and receptor are so abstract and inaccessible to objective measurement and analysis. It is not possible to instantly determine how knowledgeable, capable, experienced, effective, competent, proficient, etc. the prompter is and, at the same time, how unknowledgeable, incapable, etc. the receptor is, especially when the scaffolding is most likely to occur in advanced cognitive operations, and when the gap in the ZPD tends to be difficult to pin down. Moreover, we do not know what aspect(s) of language the prompter knows more about and the receptor knows less, especially when the scaffolding is to take place, as Ellis (2003, p. 139) and some others have emphasized, "in interaction between learners." There may also be cases of 
the kind in high proficiency levels, where a student outshines the others and even the teacher. A student, for example, may know a word or words unfamiliar to the teacher; he/she may use phrases or idioms, or even structures which have not been tried by the teacher or seem foreign to them. In addition, our knowledge is constantly growing. Nowadays, students are faced with a growing amount of exposure to foreign language resources thanks to the advancement of technology. The generational digital divide is a sharp example of the case. Now two assumptions will spring to our mind. One the one hand, taking them all as factors at one fell swoop characteristic of the individuals actually reminds us of an ideal or perfect teacher and an imperfect learner, a categorization once improperly made by Phillipson (1992) between a native speaker and nonnative speaker, respectively. More to the point, Bailey (2009), outlining Glickman, Gordon, and Ross-Gordon's (1998) key patterns of effective teachers in her book chapter on Issues in Language Teacher Evaluation, describes the identification of teacher effectiveness, one of the above-mentioned descriptive constructs, as a complex process especially in cross-cultural contexts. She says that we need to consider too many variables to find out who an effective, or outstanding, teacher is, including "the subject matter, students' ages and proficiency levels, institutional resources and constraints, and the cultural values of the educational system" (p. 708). In addition, "[a] teacher who is outstanding at one school or with learners of a certain age might be merely average in another context" (p. 711). To identify teachers of certain quality, Politzer (1970, cited in Bailey 2009) also points up that various teaching behaviors involve an optimum range, so what different teachers do in classrooms cannot be easily recognized as "good" or "bad" teaching (p. 41). On the other hand, such a rigid categorization of the prompter and receptor of assistance in learning reminds us of at least a condition where a nurse feeds a person with paralysis, in which the two opposite variables carry fixed values or definitions, or at most a case where a mother just helps her baby drink the milk (a Vygotskyan portrayal of assistance), which does not often occur in (adult) L2 learning contexts in the same way - an issue wherefore Vygotsky himself has been the target of worldwide objections.

\section{Inability zone of language production}

Another issue of concern is the time or condition in which the learner is assumed to be incapable of articulating a piece of language. It has been frequently stated (e.g., Littlewood 2004; Swain and Suzuki 2008) that the teacher supports the student to complete a task he or she would otherwise be unable to do on his or her own. The argument sparks a number of controversial issues in practical terms. First, except in certain frequently-used collocational constructions, how can a teacher or peer, who is assumed by the researchers to be more knowledgeable, etc., ever recognize the 'immediate gap' between what the student has already constructed and what is missing? To substantiate the point, it is argued that for the most part, interactional or collective scaffolding (see Donato 1994) takes place at the level of microgenesis, i.e., at the micro level of interaction, which is "neither predicted nor premeditated" (italic original) (Van Lier 2004, p. 148). Furthermore, we cannot assume any symmetrical interaction in a classroom in which the discourse members are heterogeneous in (development of) knowledge of different types, talk speed, false start, repetition, reformulation, 
simplification, code switching, topic shifting, etc. Therefore, the interaction is always asymmetric, and within the enormity of heterogeneity, this asymmetry is in most instances unknown to the interacting students. Moreover, non-native English learners, as well as inexperienced instructors, more often try to fill the coming parts of their own speech to convey the message, rather than paying heed to their partner's missing language. More importantly, the teacher is not always cognitively ready for, and even prone to, assisting a single learner to advance their discourse.

Second, the so-called scaffolding seems to be applicable more in low proficiency levels of second language learning where the grammatical and lexical structures are highly predictable to the language teachers, but not necessarily to the students. Therefore, students of high proficiency normally make less predictable and more complex constructions of L2 with more frequency and variation of lexical and syntactic structures. Cognitive processing in more advanced level of proficiency is almost impossible to tap due to its unobservable saliency and speed in production. Moreover, the more proficient the learners are, the greater use of conversational strategies they will have in actual performances (Ellis 2004; O'Malley and Chamot 1990). “This is often interpreted as indicative of the role that learning strategies play in advancing proficiency" (Ellis 2004, p. 546). So it would normally be hard for a language teacher, or a peer student, to distinguish the missing articulation in less predictable performance. Even when the gap is identified and the assistance is provided, it often turns out to be futile. Skehan (2001) provides a good reason for the case, saying that:

Far from scaffolding interlanguage development, negotiation sequences may distract the learners and overload the processing systems they are using, with the result that even when successful scaffolded negotiations occur which produce more complex language, these may not have an impact upon underlying change because there is no time to consolidate them. (p. 82)

To probe more, we will come to a fundamental question out of this second issue, and that is how does a teacher or peer identify the incapability or inability zone in a student struggling to produce the language?' Is there a common code for every L2 instructor to follow in order to detect the zone where a student fails to produce what they want to? Or does the instructor, or peer, identify exactly what has been missed in a dynamic interaction process? As far as our knowledge permits, research fails to provide such evidence. As it has been argued earlier in this paper, in low proficiency levels, there may be some recognition in certain fixed constructions, but it is almost difficult to pinpoint the zone in true higher proficiency levels, unless there may be requests for feedback and checks and for rechecks in orchestrating the old and new information in the student's dynamic utterances.

Still to support the arguments, the ZPD itself is also open to major controversies and there are questions that have remained unresolved. By and large, the ZPD notion has been reported to be a complex construct often subject to misinterpretation (e.g., Van Lier 2004; Van Patten and Bennati 2010). Despite the early conception of the ZPD assumed to regulate the interaction between learning and development (Lantolf 2005), there are voices (e.g., Ellis 1994, 2008; Lantolf 2005; Shayer 2003; Thorne and Tasker 2011; Van Greet (1998); Van Lier 2004) indicating that Vygotsky never made any 
reference to how the notion can be operationalized in the actual context of classroom because the issue of ZPD gained prominence in the research and theory after his death. Shayer (2003) also notes that the concept of the ZPD does not imply that the levels of learning are hierarchically ordered or neatly sequenced. In fact, Shayer claims that Vygotsky explicitly stated that they are not. Another persistent relevant issue is the assumption that given sporadic attempts (e.g., Dunn \& Lantolf, 1998), no one has yet clarified what the end-state distinction is between the ZPD and Krashen's (1978) notion of $i+1$, and different proposals write only about their original foundations as the former has its origin in sociocultural theory and the latter in the information processing theory of learning (e.g., Lantolf 2005). A defensible argument from Van Greet (1998), which turns out to equate the two concepts, is that “... the major function of ... help is not to offer a learning environment at the ZPD, but rather a learning environment at or around the ZPD that can also expand the ZPD” (p. 638). From a different perspective, Lantolf (2005) also points up that the fundamental assumptions concerned with the ZPD were inadequate to provide distinctions between unassisted learner performance and the performance generated through scaffolded assistance. Likewise, to demonstrate the learners' ability to perform with scaffolding in and of itself does not imply the relevance of the ZPD (Ellis 2003; also in Lantolf 2005). Having reviewed the research traditions on the sociocultural aspects of L2 learning, Mitchell and Myles (1998, 2004) questioned the issues of rates and routes of learning and development relevant to the ZPD, asserting that the Vygotskyan theory of learning offers almost nothing to address the given issues very centrally. To substantiate their claim, they therefore introduced a fundamental gap relevant to the ZPD by asking the question: Does intervention in the ZPD simply scaffold people more rapidly along common routes of interlanguage development, or can it bypass or alter these routes, by skilled co-construction? (2004, p. 222).

To wrap it up, it can be safely argued that if language learners are reported in the research to create the ZPDs - many of the findings will not be implicationally generalized due to their methodological constraints (see the section that follows) - this will occur when there is a historical identification of the learner with the teacher or his/her partner. By this, I mean that identifying the gap in the ZPD and for the assistance to be effective there, the prompter and receptor of scaffolding must have longitudinal sense of affiliation just as the one experienced in caretaker-infant or infant-infant affinity, a phenomenon that was basically embodied in Vygotsky's theory of language development.

\section{Temporary state of support}

The third, and yet final, issue that many writers suggest in relation to the scaffolding is that the assistance or support provided to the learner to develop the language in the ZPD is temporary and progressively discarded (e.g., Bailey 2006; Gibbons 2003; Van Lier 2001). It is taken for granted that the assumption is especially taken from what is construed in the actual use of scaffolding in building, as Bailey (2006) has also exemplified the point that "when the building has been constructed, painted, or repaired, the scaffolded is removed" (p. 46). The underlying reason the writers (e.g., Bailey 2006; Feez 2001; Mercer 2001) implicitly or explicitly bring to the subject matter is that the support the student receives extends to enable them to take responsibility for, or in a sense 
to self-regulate, their own learning process. The problem actually lies in both the temporariness of help and the support type.

Evidence from the recent instructed SLA research provides reservations about whether instruction has effect on L2 learning and development (see, e.g., Doughty 2003). However, the strong version is that learning takes effect when instruction is geared to negotiated interaction along with modification of input to the effect of comprehension, production and development process (e.g., Long, 1996). In other words, acquisition does not take place in a vacuum but is deeply embedded in a sociocultural milieu, which is anchored in and through the social practices (Gass and Selinker 2008) (italics added). In this process, learners need input that is comprehensible and processible. Learners get the input data during the act of comprehension, where they try to extract the target meaning from the input (Van Patten \& Benati, 2010). How this meaning is extracted and communicated is for the learners to be a matter of getting engaged in the meaningful negotiation. The degree of contextuality for changing the input to intake and the amount of exposure the learner has to the input are also significant in contributing to the acquisition of the target language aspect(s) (Gass 2004). Moreover, acquisition is determined by the constraints of developing interlanguage system over time (Doughty 2003). Moreover, we cannot ignore the fact that part of the acquisition occurs in the mind of the learners, which is not detectable unless part, not all of, the cognitive operations can be observed in the interactions, which differs from learner to leaner in terms of how long it takes to occur. This being so, the question will be 'how can the instructor identify the time limit for these learners with different rates of acquisition to declare that the learning of the target point has already been accomplished so that they can decide to diminish the support?' Moreover, 'how can they come to this conclusion that the support they have provided in a diversity of the so-called scaffolding sessions had been effective for the learners?' since the 'effectiveness' in acquisition means that there must be a change in learning (Carroll 2001) which is evident in the output (Barkhuizen 2004, p. 555) (italic original). There is no guarantee that whatever feedback types the instructor provides, such as confirmation checks, recasts, requests for clarification, etc., to correct the learners' problem(s) in the ZPD will be in the same way as expected and in the same rate of time as determined. We shouldn't even ignore the fact that acquisition is constrained by many unpredictable, changing features of a dynamically complex communicative environment, or "the hidden agenda" in Bachman and Palmer's (2010) terms, that second language learners have to attend to (Segalowitz 2003).

Our argument is that instructional assistance can never be predetermined to be either temporary or long. Learning an aspect of language and its development do not occur in a systematically rigid structure, in which the learner creates the ZPD and the teacher predicts and identifies the linguistic gap as soon as it is created and fills it with the needed comprehensible input, and then the learner receives and internalizes it and then develops it in a particular amount of time while the teacher feels assured about his/her feedback that has been effective and decides to gradually reduce the support, hoping that everything is going well in the same way, regardless of how much attentitional focus the learner brings to the input and, more importantly, how many other ZPDs the very learner is making during that time of learning. Furthermore, "teaching does not and cannot determine the way the learner's language will develop" because "[t]he processes by which the learner operates are 'natural processes' and [t]eachers and learners cannot simply 'choose' what is to be learned" (Skehan 1996, p. 19). 
It can also be a good reminder that learning is much more than the accumulation of knowledge and skills (Larsen-Freeman (2011) and "variations in cultural, ethnic, and national characteristics within and between individual students affect classroom dynamics and therefore influence the decisions teachers need to make in order to provide an optimal learning environment for all learners" (Finkbeiner 2009, p. 131). De Bot, Lowie and Verspoor (2005) clarify the condition as follows:

...optimal learning takes place when the maximal accommodation takes place, that is when the system changes maximally or when the distance between the actual level and the potential level is optimal. For different learners and different aspects to be learnt, the optimal distance between actual and potential level will vary, and accordingly the ZPD is not based on what needs to be taught, but on the characteristics of the system at a given point in time. In other words, the system creates its own ZPD and it is up to a teacher to find out for an individual learner how to make optimal use of that gap. (p. 62)

It is not surprising - it is not even senseless - to ask how the instructor can detect this optimal condition for individual learners in order to provide them with effective support. In this case, we should not forget that language instructors widely differ in the degree of professional competence in teaching.

\section{Conclusion}

Scaffolding has been used as a branch of Vygotsky's sociocultural framework of mind, which emerged primarily within the work of Bruner (1983). Since then, many second language researchers have taken much interest in targeting their thoughts and efforts at investigating the construct and its impact on L2 learning and development from a variety of angles, to the extent that there are now a wide range of perspectives and conceptions surrounding the term. There are generally two versions of approaching the term. The strong version favors an asymmetrical structure of scaffolding, asserting that interactants of unequal status can jointly construct knowledge (e.g., Duffy and Roehler 1986; Gibbons 2001, 2002). The advocates of this view argue that for scaffolding to be effective involves an expert-novice interaction in which the assistance is transmitted from the expert, e.g., a teacher, to the novice, e.g., a student, in performing the problem-solving tasks. The weak version of scaffolding focuses on the symmetrical position, although it does not reject the strong form. Those supporting the symmetrical scaffolding underscore the point that the assistance may occur among the interactants of equal status, i.e., students (Ellis 2003). The main thrust of their position is that most interaction in communicative classrooms takes place between students.

We have argued that the problem is not the assistance we as teachers provide in the classroom; rather, the conceptions underpinning the scaffolding in L2 education is logically open to questions. First of all, there is no logical association between the original nature of scaffolding and its purported implication in SLA, and we have demonstrated the claim by indicating that what was/is conceptualized of scaffolding in the physical context is at variance with what is implied in SLA in terms of predictability, variability, mediation, and restructuring. We have also shown earlier and point up here that as long as the phenomenological nature of scaffolding is at issue in SLA, we can hardly accept the definitions that have been provided 
concerning the notion. We have found three common features in the definitions of scaffolding, each with specific logical problems. Put it briefly, the rigid classification of the prompter and receptor in the assistance process is by no means logical because it is almost impossible to instantly detect how knowledgeable, for example, the prompter is and, at the same time, how unknowledgeable the receptor is, especially when the so-called notion of scaffolding is most likely to occur in advanced cognitive operations, when the gap in the $Z P D$ tends to be difficult to pin down, and when it is to take place between the learners who have unfortunately been described as the interactants of equal status. There is also no symmetrical structure of scaffolding because the differential knowledge in students is not immediately detectable. Moreover, whether or not, we must accept that knowledge in humans is variably growing.

The second problem we have found with the definition lies in the inability zone of language production. It is clear that SLA research is ambivalent toward the function of the ZPD construed by the professionals of the field decades ago. Many writers base their arguments upon the findings from a limited number of studies (e.g., Donato 1994; Ohta 1995; Nassaji and Cumming 2000; Nassaji \& Swain 2000; Swain and Lapkin 1998) that saw "the ZPD as an activity through which social patterns of interaction and mutual assistance can result in learning" (see Shrum and Glisan 2010, p. 27). However, these studies failed to indicate how they could identify the rates and routes of learning and development relevant to the ZPD (Mitchell and Myles 1998). In addition, we must no longer view the ZPD as a fixed attribute of an individual, but rather as an unpredictable nexus of people and tools in an activity to jointly create conditions for language development (Wells, 1999).

Finally, we have taken issue with the third part of the definition which is concerned with the temporariness and the type of the assistance the language teacher provides. We have argued that as far as instruction depends much on the learners' emergent needs for learning, we as teachers cannot preset the length of the assistance they need during the learning process, especially in advanced cognitive operations or when, as Widdowson (2003) put it aptly, learners are in "continual conceptual adaptation" by encoding rules and conventions for their use through sustained modifications, extensions, realignments, or abandonments, a situation that he calls to be "a process of recurrent unlearning and relearning" (p. 141). In addition, we cannot claim that the input we provide the student with is the same type of assistance he needs because, after all, the learner is constantly modifying the input to be geared to the missing knowledge. There are times when the input fails as well. Moreover, the teachers or peers are not aware of the other student's load of attention useful to manipulate the input and the other possible ZPDs the very learner is making during that time of input modification.

What makes the above discussion significant is not just the range of variation in the conceptual meaning of scaffolding but the fact that such conceptual variation causes great confusion in the operational definition of the term in the practice and research of second language acquisition.

To conclude, we would like to bring two points to the foreground: first, as long as the nature of scaffolding and the conceptual underpinnings developed in retrospection regarding the term are at stake, future studies on the notion will probably suffer a severe loss of pedagogical and intellectual significance and validity. Second, if you feel that scaffolding is the right word of use to SLA, as Van Lier (2004) also pointed out, do not use it as a magical instrument to solve whatever learning problems that come up for language learners. 
Abbreviations

L2: Second language; SLA: Second language acquisition; ZPD: Zone of Proximal Development

\section{Acknowledgements}

It is acknowledged that the present manuscript has not been published or is not under consideration in any form elsewhere.

\section{Funding}

The present manuscript has been designed and completed without receiving any funding from organizations or institutions.

\section{Authors' contributions}

All the authors of the review including ME, SR, and LS, have contributed to the conception of the study, and have been involved in drafting the manuscript or revising it critically for important intellectual content, and have given the final approval of the version to be published. Each author has participated sufficiently in the work to take responsibility for appropriate portions of the content.

\section{Authors' information}

Both authors teach ESP and EAP courses to undergraduate and MA students at Iran University of Medical Sciences.

\section{Competing interests}

The authors declare that they have no (financial or nonfinancial) competing interests.

\section{Publisher's Note}

Springer Nature remains neutral with regard to jurisdictional claims in published maps and institutional affiliations.

Received: 15 December 2017 Accepted: 18 September 2018

Published online: 26 October 2018

\section{References}

Applebee, A. N., \& Langer, J. (1983). Instructional scaffolding: Reading and writing as natural language activities. Language Arts, 60(2), 168-175.

Bachman, L. F., \& Palmer, A. S. (2010). Language assessment in practice. Oxford: Oxford University Press.

Bailey, K. M. (2006). Language teacher supervision: A case-based approach. Cambridge: Cambridge University Press.

Bailey, K. M. (2009). Issues in language teacher evaluation. In M. H. Long \& C. J. Doughty (Eds.), The handbook of language teaching (pp. 706-725). Oxford: Blackwell. https://doi.org/10.1002/9781444315783.

Barkhuizen, G. (2004). Social influences on language learning. In A. Davies \& C. Elder (Eds.), The handbook of applied linguistics (pp. 552-575). Oxford: Blackwell.

De Bot, K., Lowie, W., \& Verspoor, M. (2005). Second language acquisition: An advanced resource book. USA: Routledge. DOl: https://doi.org/10.1075/sl.30.4.08.

Breen, M. (1989). Navigating the discourse: On what is learned in the language classroom. In W. Renandya \& G. Jacobs (Eds.), Learners and language learning. Singapore: SEAMEO Regional Language Centre.

Breen, M. (2001). The social context for language learning: A neglected situation? In C. Kramsch (Ed.), Language acquisition and language socialization (pp. 122-145). London: Continuum. https://doi.org/10.1017/S0272263100005337.

Bruner, J. S. (1983). The acquisition of pragmatic commitments. In R. Golinkoff (Ed.), The transition from prelinguistic to linguistic communication (pp. 27-42). Hillsdale: Erlbaum.

Carroll, S. (2001). Input and evidence. Amsterdam: John Benjamins.

Cotterall, S., \& Cohen, R. (2003). Scaffolding for second language writers: Producing an academic essay. ELT Journal, 57, 158166. https://doi.org/10.1093/elt/57.2.158.

De Guerrero, M. C. G., \& Villamil, O. S. (2000). Activating the ZPD: Mutual scafforlding in L2 peer revision. The Modern Language Journal, 84, 51-68. Doi.org/https://doi.org/10.1111/0026-7902.00052.

Donato, R. (1994). Collective scaffolding in second language learning. In J. Lantolf \& G. Appel (Eds.), Vygotskian approaches to second language research. Norwood: Ablex.

Donato, R. (2000). Sociocultural contributions to understanding the foreign and second language classroom. In J. P. Lantolf (Ed.), Sociocultural theory and second language learning (pp. 27-50). Oxford: Oxford University Press.

Doughty, C. (2003). Instructed SLA: Constraints, compensation and enhancement. In C. Doughty \& M. Long (Eds.), The handbook of second language acquisition (pp. 256-310). Malden: Blackwell. https://doi.org/10.1002/9780470756492.

Duffy, G. G., \& Roehler, L. R. (1986). The subtleties of instructional mediation. Educational Leadership, 43, 23-27 DOI: Eric.ed. gov/?id=EJ338716.

Dunn, W. E., \& Lantolf, J. P. (1998). Vygotsky's Zone of Proximal Development and Krashen's i + 1: Incommensurable constructs; incommensurable theories. Language Learning, 48(3), 411-442.

Ellis, R. (1990). Instructed second language acquisition. Oxford: Blackwell.

Ellis, R. (1994). The study of second language acquisition. Oxford: Oxford University Press. https://doi.org/10.2307/329065.

Ellis, R. (2003). Task-based language learning and teaching. Oxford: Oxford University Press. https://doi.org/10.1080/09571736.2016.1236523.

Ellis, R. (2004). Individual differences in second language learning. In A. Davies \& C. Elder (Eds.), The handbook of applied linguistics (pp. 525-551). Oxford: Blackwell.

Ellis, R. (2008). Principles of instructed second language learning. CAL Digest. RetrievedAugust 15, 2011, from http://www.cal. org/resources/digest/instructed2ndlang.htm

Feez, S. (2001). Curriculum evolution in the Australian adult migirant English program. In D. R. Hall \& A. Hewings (Eds.), Innovations in English language teaching: A reader (pp. 208-228). London \& New York: Routledge.

Finkbeiner, C. (2009). Culture and good language learners. In C. Griffiths (Ed.), Lessons from good language learners (pp. $131-$ 142). Cambridge: Cambridge University Press. https://doi.org/10.1017/CBO9780511497667. 
Gass, S. (2004). Conversation and input-interaction. Modern Language Journal, 88, 597-616. https://doi.org/10.1111/j.15404781.1998.tb01211.

Gass, S., \& Selinker, L. (2008). Second language acquisition: An introductory course (3rd ed.). London: Routledge.

Gibbons, P. (2001). Learning a new register in a second language. In C. N. Candlin \& N. Mercer (Eds.), English language teaching in its social context: A reader (pp. 258-270). London, New York: Routledge. https://doi.org/10.2307/3588440.

Gibbons, P. (2002). Scaffolding language, scaffolding learning. Portsmouth: Heinemann.

Gibbons, P. (2003). Scaffolding academic language across the curriculum. Presentation at American Association for Applied Linguistics, Arlington, VA, March 25, 2003.

Johnson, K. E. (2009). Second language teacher education: A sociocultural perspective. New York: Routledge. https://doi.org/10. $1177 / 1362168810365254$.

Karmiloff-Smith, A. (1986). Stage/structure versus phase/process in modeling linguistic and cognitive development. Retrieved from www.psy.cmu.edu/ siegler/Karm-Smith86.pdf.

Krashen, S. D. (1987). Principles and practice in second language acquisition. Prentice-Hall International.

Lantolf, J. P. (2000a). Second language learning as a mediated process. Language Teaching, 33(2), 79-96. https://doi.org/10. 1017/S0261444800015329.

Lantolf, J. P. (Ed.). (2000b). Sociocultural theory and second language learning. Oxford: Oxford University Press.

Lantolf, J. P. (2005). Sociocultural and second language learning research: An exegesis. In E. Hinkle (Ed.), Handbook of research in second language teaching and learning (Vol. I) (pp. 335-355). Oxford: Routledge. https://doi.org/10.1017/ S0272263106260297.

Lantolf, J. P. (2009). Knowledge of a foreign language in teacher education. Modern Language Journal, 93, 270-274. https:// doi.org/10.1111/j.1540-4781.2009.00860_4.

Lantolf, J. P. (2011). The sociocultural approach to second language acquisition: Sociocultural theory, second language acquisition, and artificial L2 development. In D. Atkinson (Ed.), Alternative approaches to SLA (pp. 24-47). New York: Routledge. https://doi.org/10.1111/j.1540-4781.2012.1306_2.

Larsen-Freeman, D. (2011). Key concepts in language learning and language education. In J. Simpson (Ed.), The Routledge handbook of applied linquistics (pp. 155-170). London: Routledge. https://doi.org/10.4324/9780203835654.

Larsen-Freeman, D. (1991). Second language acquisition research: Staking out the territory. TESOL Quarterly, 25, 315-350. https://doi.org/10.2307/3587466/pdf.

Lightbown, P. M. (1985). Great expectations: second language acquisition research and classroom teaching. Applied Linguistics, 6(2), 173-189. https://doi.org/10.1093/applin/6.2.173.

Littlewood, W. (2004). Second language learning. In A. Davies \& C. Elder (Eds.), The handbook of applied linguistics (pp. 501524). Oxford: Blackwell. https://doi.org/10.1002/9780470757000.

Long, M. H. (1996). Authenticity and learning potential in L2 classroom discourse. In G. M. Jacobs (Ed.), Language classrooms of tomorrow: Issues and responses (pp. 148-169). Singapore: SEAMEO Regional Language Centre.

Macaro, E., Vanderplank, R., \& Murphy, V. A. (2010). A compendium of key concepts in second language acquisition. In E. Macaro (Ed.), The continuum companion to second language acquisition (pp. 29-106). London: Continuum.

McLaughlin, B. (1987). Theories of second language learning. London: Edward Arnold.

McLaughlin, B. (1990). Restructuring. Applied Linguistics, 11, 113-128.

Mercer, N. (2001). Language for teaching a language. In C. N. Candlin \& N. Mercer (Eds.), English language teaching in its social context: A reader (pp. 243-257). London, New York: The Open University.

Mitchell, R., \& Myles, F. (1998). Second language learning theories (1st ed.). London: Arnold.

Mitchell, R., \& Myles, F. (2001). Second language learning: Key concepts. In C. N. Candlin \& N. Mercer (Eds.), English language teaching in its social context: A reader (pp. 11-27). London, New York: Routledge. https://doi.org/10.2307/3588440.

Mitchell, R., \& Myles, F. (2004). Second language learning theories (2nd ed.). London: Arnold.

Myles, F., Hooper, J., \& Mitchell, R. (1998). Rote or rule? Exploring the role of formulaic language in classroom foreign language learning. Language Learning, 48, 323-363.

Nassaji, H., \& Cumming, A. (2000). What's in a ZPD? A case study of a young ESL student and teacher interacting through dialogue journals. Language Teaching Research, 4, 95-121.

Nassaji, H., \& Fotos, S. (2011). Teaching grammar in second language classrooms: Integrating form-focused instruction in communicative context. New York: Routeledge.

Nyikos, M., \& Hashimoto, R. (1997). Constructivist theory applied to collaborative learning in teacher education: In search of ZPD. Modern Language Journal, 81(4), 506-517.

O'Malley, J. M., \& Chamot, A. U. (1990). Learning strategies in second language acquisition. Cambridge: Cambridge University Press.

Ohta, A. S. (1995). Applying sociocultural theory to an analysis of learner discourse: Learner-learner collaborative interaction in the zone of proximal development. Issues in Applied Linguistics, 6, 93-121.

Phillipson, R. (1992). Linguistic imperialism. Oxford: Oxford University Press.

Rogoff, B. (1990). Apprenticeship in thinking. Cambridge: Cambridge University Press Retrieved from https://ase.tufts.edu/ DevTech/courses/readings/Rogoff-DevelopingUnderstanding.pdf.

Saville-Troike, M. (2006). Introducing second language acquisition. Cambridge: Cambridge University Press.

Scollon, R. (2001). Cross-cultural learning and other catastrophes. In C. Kramsch (Ed.), Language acquisition and language socialization: Ecological perspectives (pp. 121-139). London: Continuum. https://doi.org/10.1017/S0272263100005337.

Scollon, R. (2002). Cross-cultural learning and other catastrophes. In C. Kramsch (Ed.), Language acquisition and language socialization (pp. 121-139). London: Continuum. https://doi.org/10.1111/0026-7902.00071.

Seedhouse, P. (2004). The interactional architecture of the language classroom: A conversation analysis perspective. Malden: Blackwell.

Seedhouse, P. (2010). The relationship between pedagogical focus and interaction in L2 lessons. In E. Macaro (Ed.), The continuum companion to second language acquisition (pp. 220-246). London: Continuum.

Segalowitz, N. (2003). Automaticity and second languages. In C. Doughty \& M. Long (Eds.), The handbook of second language acquisition (pp. 382-408). Oxford: Blackwell Publishing. https://doi.org/10.1002/9780470756492.

Shayer, M. (2003). Not just Piaget, not just Vygotsky, and certainly not Vygotsky as an alternative to Piaget. Learning and Instruction, 13, 465-485. https://doi.org/10.1016/S0959-4752(03)00092-6. 
Shrum, J. L., \& Glisan, E. W. (2010). Teacher's handbook: Contextualized language instruction (4th ed.). Canada: Heinle, Cengage Learning. https://doi.org/10.1111/j.1540-4781.2011.01212_6.

Skehan, P. (1996). Second language acquisition research and task-based instruction. In D. Willis \& J. Willis (Eds.), Challenge and change in language teaching. London: Heinemann.

Skehan, P. (2000). A cognitive approach to language learning. Oxford: Oxford University Press.

Skehan, P. (2001). Comprehension and production strategies in language teaching. In C. N. Candlin \& N. Mercer (Eds.), English language teaching in its social context: A reader (pp. 75-89). London: New York: Routledge. https://doi.org/10.2307/3588440.

Storch, N. (2002). Patterns of interaction in ESL pair work. Language Learning, 52(1), 119-158. https://doi.org/10.1111/14679922.00179

Swain, M. (2000). The output hypothesis and beyond: Mediating acquisition through collaborative dialogue. In J. Lantolf (Ed.), Sociocultural theory and second language learning (pp. 94-114). Oxford: Oxford University Press. https://doi.org/10.1017/ S0272263102223062.

Swain, M., \& Lapkin, S. (1998). Interaction and second language learning: Two adolescent French immersion students working together. The Modern Language Journal, 82(3), 320-337. https://doi.org/10.1111/j.1540-4781.1998.tb01209.

Swain, M., \& Suzuki, W. (2008). Interaction, output, and communicative language learning. In B. Spolsky \& F. M. Hult (Eds.), The handbook of educational linguistics (pp. 557-570). Oxford: Blackwell. https://doi.org/10.1002/9780470694138.fmatter/pdf.

Tarone, E. (1990). On variation in interlanguage: A response to Gregg. Applied Linguistics, 11, 392-399. https://doi.org/10.1093/ applin/11.4.392.

Thorne, S. L., \& Tasker, T. (2011). Sociocultural and cultural-historical theories of language development. In J. Simpson (Ed.) The Routledge handbook of applied linguistics (pp. 487-500). London: Routledge. https://doi.org/10.4324/9780203835654.

Van Greet, P. (1998). A dynamic systems model of basic developmental mechanisms: Piaget, Vygotsky, and beyond. Psychological Review, 105(4). 634-677. https://doi.org/10.1111/1467-8721.00062.

Van Lier, L. (1992). Not the nine o'clock linguistics class: Investigating contingency grammar. Language Awareness, 1(2), $91-$ 108. https://doi.org/10.1080/09658416.

Van Lier, L. (1996). Interaction in the language curriculum: Awareness, autonomy and authenticity. London: Longman. https:// doi.org/10.2307/3588055/pdf.

Van Lier, L. (2004). The ecology and semiotics of language learning: A sociocultural perspective. Boston: Kuhler. https://doi.org/10. 1007/1-4020-7912-5.

Van Lier, L. (2001). Constraints and resources in classroom talk: Issues of equality and symmetry. In C. N. Candlin \& N. Mercer (Eds.), English language teaching in its social context: A reader (pp. 90-109). London, New York: The Routledge. https://doi. org/10.2307/3588440

Van Patten, B., \& Banati, A. G. (2010). Key Terms in Second Language Acquisition. London: Continuum.

Vygotsky, L. (1978). Interaction between learning and development. Readings on the development of children, 23(3), 34-41.

Watson-Gegeo, K. A., \& Nielsen, S. (2003). Language socialization in SLA. In C. Doughty \& M. Long (Eds.), The handbook of second language acquisition (pp. 155-177). Malden: Blackwell. https://doi.org/10.1002/9780470756492.

Weissberg, R. (2006). Connecting speaking and writing in second language writing instruction. Michigan: University of Michigan Press. https://doi.org/10.1002/j.1545-7249.

Wells, G. (1999). Dialogic inquiry: Towards a sociocultural practice and theory of education. Cambridge: Cambridge University Press. Widdowson, H. G. (2003). Defining issues in English language teaching. Oxford: Oxford University Press.

\section{Submit your manuscript to a SpringerOpen ${ }^{\circ}$ journal and benefit from:}

- Convenient online submission

- Rigorous peer review

- Open access: articles freely available online

- High visibility within the field

- Retaining the copyright to your article

Submit your next manuscript at $\mathbf{s p r i n g e r o p e n . c o m ~}$ 